\title{
DAMPAK APLIKASI PERILAKU CARING DALAM PENDIDIKAN TAHAP PROFESI NERS: STUDI FENOMENOLOGI
}

\author{
Impact of Caring Behavior in Stage Professional Education Ners: Phenomenology Study
}

\author{
Afina Muharani Syaftriani ${ }^{1}$, Muchti Yuda Pratama ${ }^{2}$ \\ ${ }^{1}$ Dosen Akademi Keperawatan Kesdam I/Bukit Barisan Medan \\ Email: afinalubis@gmail.com \\ ${ }^{2}$ Dosen Akademi Keperawatan Kesdam I/Bukit Barisan Medan \\ Email: yudamuchti@yahoo.co.id, muchtiyuda@gmail.com
}

\begin{abstract}
Abstrak
Perilaku caring adalah suatu tindakan yang didasari oleh kepedulian, kasih sayang, keterampilan, empati, tanggung jawab, sensitif dan dukungan. Pemberian pelayanan keperawatan yang didasari oleh perilaku caring mampu meningkatkan kualitas pelayanan kesehatan. Perilaku caring tidak hanya dilakukan oleh perawat tetapi juga dilakukan oleh mahasiswa yang sedang menjalankan tahap pendidikan profesi ners di rumah sakit. Aplikasi perilaku caring pada mahasiswa dalam tahap pendidikan profesi ners sangat penting diterapkan karena ini adalah tempat pertama bagi mahasiswa untuk belajar tentang nilai-nilai dan esensi dari profesi mereka. Penelitian ini bertujuan untuk mengeksplorasi dampak aplikasi perilaku caring dalam pendidikan tahap profesi ners. Penelitian ini menggunakan desain fenomenologi. Teknik pengambilan sampel yang digunakan adalah purposive sampling dengan jumlah partisipan sebanyak sepuluh orang partisipan. Pengambilan data dilaksanakan di Fakultas Keperawatan Universitas Sumatera Utara dari bulan Februari sampai dengan April 2015. Analisa data pada penelitian ini menggunakan metode Collaizi. Penelitian ini menemukan 5 tema dampak aplikasi perilaku caring dalam pendidikan tahap profesi ners, yaitu 1) mahasiswa profesi ners mengalami kepuasaan batin, 2) mahasiswa profesi ners merasa senang, 3) pasien merasa nyaman, 4) mempercepat proses penyembuhan pasien, dan 5) pengetahuan pasien bertambah. Mengingat besarnya dampak perilaku caring tersebut, maka direkomendasikan kepada mahasiswa pendidikan tahap profesi ners untuk terus meningkatkan perilaku caring kepada pasien. Selanjutnya, bagi institusi pendidikan keperawatan ataupun rumah sakit dapat membuat standar perilaku caring sehingga dapat meningkatkan kualitas pelayanan kepada pasien.
\end{abstract}

Kata Kunci: dampak perilaku caring, pendidikan tahap profesi ners, studi fenomenologi

\begin{abstract}
Caring behavior is an act based on caring, affection, skill, empathy, responsibility, sensitivity and support. Provision of nursing services based on caring behavior can improve the quality of health services. Caring behavior is not only performed by nurses but also performed by students who are running the professional education phase ners in the hospital. The application of caring behavior to students in professional education is very important because it is the first place for students to learn about the values and essence of their profession. This study aims to explore the impact of caring behavioral application in professional education stage ners. This research uses phenomenology design. The sampling technique used was purposive sampling with a total of ten participants. The data was collected at Nursing Faculty of University of Sumatera Utara from February to April 2015. Data analysis in this research used Collaizi method. This study found 5 themes of caring behavioral application impact in professional education ners stage, that is 1) professional students ners experiencing inner satisfaction, 2) professional students ners feel happy, 3) patients feel comfortable, 4) accelerate the healing process of patients, and 5) knowledge patient increases. Given the magnitude of the impact of caring behavior, it is recommended to students of professional education stage ners to continue to improve caring behavior to patients. Furthermore, for nursing education institutions or hospitals can create caring behavior standards so as to improve the quality of service to patients.
\end{abstract}

Keywords: impact of caring behavior, professional education stage ners, phenomenology study

\section{PENDAHULUAN}

Caring secara umum dapat diartikan sebagai suatu kemampuan untuk berdedikasi bagi orang lain, pengawasan dengan waspada, menunjukkan perhatian, perasaan empati pada orang lain dan perasaan cinta atau menyayangi yang merupakan kehendak keperawatan (Potter, 2005). Perilaku caring sangat penting bagi perawat yang bertugas di rumah sakit. Perawat yang caring, cerdas dan terampil akan memberikan keamanan, kenyamanan dan kepuasan pada klien dan keluarga serta 
membawa dampak positif terhadap citra rumah sakit, citra profesi perawat di mata klien, keluarga bahkan masyarakat pada umumnya (Gaghiwu, 2013). Perilaku caring tidak hanya dilakukan oleh perawat tetapi juga dilakukan oleh mahasiswa tahap pendidikan profesi ners. Aplikasi perilaku caring pada mahasiswa dalam tahap pendidikan profesi ners sangat penting diterapkan karena ini adalah tempat pertama bagi mahasiswa untuk belajar tentang nilai-nilai dan esensi dari profesi mereka (Begum, 2012).

\section{TINJAUAN PUSTAKA}

Perilaku caring menurut Watson (1979) adalah proses yang dilakukan perawat meliputi pengetahuan, tindakan dan dideskripsikan sebagai sepuluh faktor karatif yang digunakan dalam praktik keperawatan di beberapa setting klinik yang berbeda (Tomey, 2006).

Watson (1979) menambahkan bahwa caring yang dilakukan dengan efektif dapat mendorong kesehatan dan pertumbuhan individu $^{[4]}$. Selain itu, perilaku caring perawat memberi pengaruh dalam pelayanan yang berkualitas pada pasien (Prompahakul, 2011). Perilaku caring perawat juga memberikan kontribusi besar terhadap kualitas pengalaman pasien selama dilakukan perawatan (Wolf, 2003).

Perilaku caring juga dilakukan oleh mahasiswa yang sedang melaksanakan pendidikan tahap profesi ners. Mahasiswa keperawatan akan memulai program pendidikan tahap profesi ners setelah lulus dari program pendidikan akademik. Pada pendidikan tahap profesi ners, mahasiswa akan mengaplikasikan seluruh pengetahuan dan teori yang telah didapat selama pendidikan akademik ke dalam masalah klinik yang nyata (Nurhidayah, 2011).

Salah satu penerapan perilaku caring mahasiswa tahap pendidikan profesi ners adalah kehadiran.Kehadiran disini meliputi keberadaan mahasiswa profesi ners dalam memberikan waktunya untuk mendengarkan secara aktif dan sensitif terhadap pasien yang mereka rawat. Perilaku caring lainnya meliputi mendukung dan memberikan perhatian ke pasien tanpa mengharapkan imbalan apa pun, menunjukkan rasa hormat terhadap pasien, berbicara dengan pasien dan bersikap jujur dengan pasien (Schaefer, 2003).

\section{METODE}

Partisipan. Partisipan pada penelitian ini terdiri dari sepuluh orang mahasiswa Fakultas Keperawatan Universitas Sumatera Utara semester 2 yang sedang menjalankan program pendidikan profesi ners dan berasal dari program reguler (mahasiswa jalur A). Metode pengambilan sampel dengan menggunakan metode purposive sampling.

Pengumpulan data. Pengumpulan data dilakukan dengan in-depth interview.

Analisa data. Proses analisa data dilakukan segera setelah selesai setiap satu proses wawancara, yaitu bersamaan dengan dibuatnya transkrip wawancara. Data yang diperoleh dianalisis dengan menggunakan metode Collaizi.

Pertimbangan etik. Pengumpulan data dilakukan setelah mendapat izin dari Dekan Fakultas Keperawatan Universitas Sumatera Utara dan memperoleh ethical clearance dari Komisi Etik Penelitian Kesehatan Fakultas Keperawatan Universitas Sumatera Utara. Selanjutnya peneliti menjelaskan tujuan, manfaat dan prosedur pelaksanaan penelitian kepada calon partisipan dan bila partisipan bersedia berpartisipasi dalam penelitian ini maka partisipan diminta untuk menandatangi surat persetujuan sebagai partisipan (informed consent).

\section{HASIL PENELITIAN}

Penelitian ini menemukan 5 tema dampak aplikasi perilaku caring dalam pendidikan tahap profesi ners, yaitu 1) mahasiswa profesi ners mengalami kepuasaan batin, 2) mahasiswa profesi ners merasa senang, 3) pasien merasa nyaman, 4) mempercepat proses penyembuhan pasien, dan 5) pengetahuan pasien bertambah.

\subsection{Mahasiswa profesi ners mengalami kepuasan batin}

Perilaku caring yang dilakukan mahasiswa profesi ners memiliki banyak dampak kepada mereka. Dampak perilaku caring yang dirasakan partisipan pada penelitian ini antara lain mahasiswa profesi ners mengalami kepuasan batin. Kepuasan batin disini dimaksudkan partisipan dengan partisipan merasa puas sudah memberikan pelayanan yang baik kepada pasien. Hal ini sesuai dengan pernyataan berikut: 
"Efek dari caring itu sendiri yang pertama itu kita merasa puas dengan apa yang kita lakukan. Jadi ketika pasien merasa nyaman dengan tindakan kita kan ada kepuasan tersendiri bagi kita. Oh ini memang perawat ini memang bagus untuk kita",

(Partisipan 1)

Partisipan
merasakan dalam penelitian ini juga
kepuasan mengaplikasikan perilaku caring karena mereka dapat merubah persepsi keluarga tentang perawat. Banyak keluarga pasien mengatakan bahwa perawat sekarang ramah-ramah. Hal ini sesuai dengan pernyataan partisipan berikut:

"Malah ada pengalaman kakak, ada keluarga gitu kan, kan baru datang gitu kan. nah ketika kakak masuk gitu kan mau melakukan pengkajian, biasa kan kalau misalnya pasien baru itu pasti dilakukan pengkajian kan. Nah ketika kakak datang apa yang dibilang mereka.."Perawat sekarang sudah berubah ya? Sekarang udah ramahramah"gitu kan.. udah berubah.. jadi selama ini mereka berfikir perawat itu jutek"

(Partisipan 1)

\subsection{Mahasiswa profesi ners merasa senang}

Beberapa partisipan pada penelitian ini merasakan adanya rasa senang pada diri mereka setelah menerapkan perilaku caring pada pasien. Kesenangan yang dirasakan partisipan pada penelitian ini dikarenakan setelah menerapkan perilaku caring pada pasien, partisipan menjadi dikenal dengan pasien. Hal ini sesuai dengan pernyataan dibawah ini:

"Terus mereka jadi kenal sama kakak. Karena kan dari awal tadi kan kita sudah bina trust, kita juga setiap tindakan kita juga memperkenalkan diri, jadi mereka juga kenal nama kita"

(Partisipan 8)

Partisipan pada penelitian ini juga merasa senang setelah menerapkan perilaku caring kepada pasien karena dengan mereka berperilaku caring, pasien menjadi mencari-cari mereka jika tidak ada diruangan. Sesuai dengan pernyataan berikut:
"Karna awalnya kita uda kenalan sama mereka. "mana perawat yang ini kok ga nampak ya?" Nah ketika nanti kita dinas sore.. "Ooo tadi ibu cari-cari ini perawatnya" katanya kayak gitu kan,. "Oiya ibu nyari-nyari ya Bu? Oiya saya dinas sore".. kakak bilang kayak gitu. "Oiya tadi saya ada perlu tapi tengok ni perawat-perawat disini ga peduli sama saya makanya saya mau minta tolong kamu" katanya kayak gitu.. Pasti dicari sama pasien kita"

(Partisipan 1)

\subsection{Pasien merasa nyaman}

Perilaku caring yang dilakukan mahasiswa profesi ners juga berdampak pada pasien. Hasil analisa data pada penelitian ini didapatkan salah satu dampak yang dirasakan pasien setelah diterapkannya perilaku caring adalah pasien merasa nyaman. Pasien merasa nyaman dengan mahasiswa profesi ners dicontohkan partisipan dengan pasien hanya mau dirawat dengan mahasiswa profesi ners. Sesuai dengan pernyataan berikut:

"Ada sih pasien merasa nyaman, ada juga sampai pasien ga mau pulang, disini perawatnya baik-baik, ada yang kayak gitu juga jadinya"

(Partisipan 7)

Dengan diterapkannya perilaku caring kepada pasien, pasien menjadi percaya dengan mahasiswa profesi ners. Maksudnya disini adalah pasien hanya percaya pada mahasiswa profesi ners untuk melakukan tindakan keperawatan kepadanya. Hal ini sesuai dengan pernyataan dibawah ini:

"Percaya disini misalkan dalam
melakukan tindakan keperawatan
mereka lebih percaya kita yang
mengerjakan. Dan kita jadi tempat
bertanya mereka. Dari situ kan peran
kita sebagai perawat juga sebagai
edukator kan, jadi itu sejalan semuanya
bisa dikerjakan" (Partisipan 10)

Pasien juga merasa diperhatikan dari sebelumnya setelah partisipan menerapkan perilaku caring kepadanya, sesuai dengan pernyataan berikut: 
"Manfaat buat pasiennya mereka merasa lebih diperhatikan dari sebelumnya. Sering mereka bilangnya, "Sebelum ada kalian kami ga pernah diperhatikan, kami ga pernah ditanya"

(Partisipan 4)

Dengan diterapkannya perilaku caring, pasien juga menjadi lebih terbuka dengan mahasiswa profesi ners. Pasien menjadi lebih terbuka untuk menceritakan keluhannya kepada mahasisa profesi ners. Hal ini sesuai dengan pernyataan berikut:

"Selain itu palingan pasien merasa lebih terbuka dengan saya. Apapun keluhan mereka, mereka langsung menyampaikan, apapun yang..masalah yang mereka hadapi, mereka menceritakannya ke saya"

(Partisipan 6)

\subsection{Mempercepat proses penyembuhan pasien}

Beberapa partisipan pada penelitian ini mengatakan dengan diterapkan perilaku caring maka dapat mempercepat proses penyembuhan pasien. Sesuai dengan pernyataan berikut:

"Manfaat yang lain ya karena kita caring misalnya pasiennya resiko infeksi, karna kita sering observasi dan penatalaksaan infeksi dia lebih ini..lebih cepat lah proses penyembuhannya dari pada yang sebelumnya"

(Partisipan 4)

Selain mempercepat proses penyembuhan pasien, dampak perilaku caring bagi pasien yang lain adalah pasien menjadi lebih semangat menghadapi penyakitnya. Hal ini sesuai dengan pernyataan dibawah ini:

"Maksudnya mereka jadi semangat sih menghadapi penyakitnya gitu kan. Misalnya ketika pasien menghadapi sakit yang seperti itu dengan adanya support system, dengan adanya perawat yang caring itu dan keluarga yang mendampinginya dia akan apa ya.. kopingnya jadi adaptif. Justru tidak membuat dia down, dan dia akan terus berjuang melawan sakitnya karna kan dengan penjelasan yang terapeutik juga kan dari perawat itu sangat membantu sih dek"

(Partisipan 10)

\subsection{Pengetahuan pasien bertambah}

Perilaku caring juga membuat pengetahuan pasien bertambah. Maksudnya disini adalah, dengan kita berperilaku caring salah satu contohnya yaitu menjelaskan keluhan pasien secara rasional ataupun dengan memberikan penkes, maka pasien dapat menambah pengetahuan mereka mengenai bagaimana mengatasi keluhan yang mereka rasakan, sesuai dengan pernyatan berikut:

\section{"Mereka dapat lebih menambah pengetahuan mereka juga, bagaimana mengatasi keluhan yang mereka keluhkan"}

(Partisipan 6)

\section{PEMBAHASAN}

Perilaku caring telah terbukti memberikan dampak yang sangat besar bagi pasien maupun perawat. Dampak perilaku caring yang dikemukakan partisipan salah satunya adalah dengan partisipan berperilaku caring maka dapat merubah persepsi keluarga pasien pada perawat. Banyak pasien dan keluarga pasien mengatakan perawat sekarang ramah-ramah. Hal ini sesuai dengan hasil penelitian Gaghiwu, Ismanto dan Babakal (2013) menunjukkan bahwa sebagian besar pasien menyatakan perilaku caring perawat sudah baik, pasien berpendapat bahwa perawat sekarang lebih ramah dan bersedia menjelaskan dengan sabar ketika keluarga pasien bertanya tentang kondisi pasien, berbeda dengan perawat zaman dahulu.

Hasil penelitian juga menjelaskan bahwa dengan adanya perilaku caring dapat membina hubungan yang baik antara mahasiswa profesi ners dan pasien. Hal ini sejalan dengan penelitian Setiawan, Hatthakit, Boonyoung dan Engebretson (2010) dimana didapatkan hasil bahwa manfaat perilaku caring pada perawat salah satunya adalah dapat menjalin hubungan yang lebih dekat dengan pasien dan meningkatkan kepercayaan yang lebih besar kepada pasien dan keluarga.

Dampak perilaku caring bagi pasien yang lain adalah pasien merasa nyaman dengan mahasiswa profesi ners. Pada studi kualitatif oleh Finch (2008) mengenai dampak perilaku 
caring juga didapatkan hasil bahwa terjadi peningkatan kesehatan pasien ke arah yang lebih baik, peningkatan fisik dan emosional. Secara fisik klien menjadi lebih nyaman, memiliki pengetahuan yang lebih mengenai status kesehatan mereka, lebih tenang, santai, dan peningkatan pandangan hidup.

Seseorang yang sakit bila diperlakukan seperti keluarga sendiri dan diperlakukan dengan penuh kasih sayang pasti akan berdampak baik, pasien yang dirawat oleh perawat akan lebih mempercayai perawat dalam melakukan tindakan dan juga membantu proses penyembuhan yang lebih cepat. Hal ini juga sesuai dengan hasil penelitian dimana partisipan mengatakan dengan perilaku caring yang mereka terapkan kepada pasien, pasien menjadi percaya dengan mahasiswa profesi ners sehingga dapat mempercepat proses penyembuhan pasien.

\section{KESIMPULAN}

Berdasarkan hasil wawancara mendalam yang dilakukan terhadap sepuluh partisipan, maka penelitian ini menemukan 5 tema dampak aplikasi perilaku caring dalam pendidikan tahap profesi ners, yaitu 1) mahasiswa profesi ners mengalami kepuasaan batin, 2) mahasiswa profesi ners merasa senang, 3) pasien merasa nyaman, 4) mempercepat proses penyembuhan pasien, dan 5) pengetahuan pasien bertambah. Mengingat besarnya dampak perilaku caring tersebut, maka direkomendasikan kepada mahasiswa pendidikan tahap profesi ners untuk terus meningkatkan perilaku caring kepada pasien. Selanjutnya, bagi institusi pendidikan keperawatan ataupun rumah sakit dapat membuat standar perilaku caring sehingga dapat meningkatkan kualitas pelayanan kepada pasien.

\section{DAFTAR PUSTAKA}

Begum, S., \& Slavin, H. 2012. Perceptions of "Caring" in Nursing Education by Pakistani Nursing Students: An exploratory study. Nurse Education Today, 32(3), 332-336. doi:10.1016/j.nedt.2011.10.011.

Gaghiwu, L., Ismanto, A.Y., \& Babakal, A. 2013. Hubungan Perilaku Caring Perawat dengan Stres Hospitalisasi pada Anak Usia Toddler di Irina E BLU RSUP Prof. Dr. R. Kandou Manado. ejournal Keperawatan (e-Kp). 1(1): 1-7
Glembocki, M.M., \& Dunn, K.S. 2010. Building an Organizational Culture of Caring: Caring Perceptions Enhanced With Education. The Journal of Continuing Education in Nursing. 41(12): $\quad$ 565-570. doi:10.3928/00220124-20100701-05

Nurbiyati, T. (2013). Persepsi Pasien Tentang Perilaku Caring Perawat dalam Pelayanan Keperawatan. Prosiding Konferensi Nasional PPNI Jawa Tengah 2013: 256-261

Nurhidayah, R.E. 2011. Pendidikan Keperawatan. Medan: USU Press

Potter, P.A., \& Perry, A.G. 2005. Fundamental of Nursing : Concepts, Process \& Practice. $6^{\text {th }}$ ed. St Louis, MI: Elsevier Mosby

Pratama, M.Y. 2017. Analisis Kualitas Kehidupan Kerja Perawat Pelaksana di Rumah Sakit Putri Hijau Medan. Jurnal Ilmiah Penelitian Kesehatan (Jumantik). http://www.jurnal.uinsu.ac.id/index.php /kesmas/article/view/1192, tanggal akses 13 Mei 2017.

Prompahakul, C., Nilmanat, K., \& Kongsuwan, W. 2011. Nurses' Caring Behavior for Dying Patient in Southern Thailand. Nurse Media Journal of Nursing. 1(2): $147-158$

Schaefer, K.M. 2003. Caring Behaviors of Advanced Practice Nursing Students. Journal of Holistic Nursing. 21(1): 3651. doi:10.1177/0898010102250274

Setiawan., Hatthakit, U., Boonyoung, N., \& Engebretson, J.C. 2010. Creating a Caring Atmosphere in an Intensive Stroke Care Unit in Indonesia: An Action Research Approach. Malaysian of Nursing Journal: 1-10

Tomey, A.M., \& Alligood, M.R. 2006. Nursing Theorist and Their Work. $6^{\text {th }}$ ed. Philadelphia: Mosby Year - Book Inc

Wolf, Z.R., Miller, P.A., \& Devine, M. 2003. Relationship Between Nurse Caring and Patient Satisfaction in Patients Undergoing Invasive Cardiac Procedures. Medical Surgical Nursing. 12(6): 391-396 